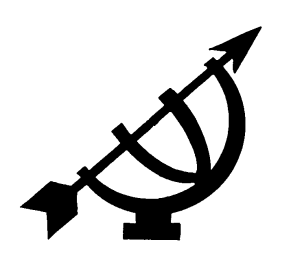

\title{
The idea of lingual economy
}

\author{
A. Weideman \\ Unit for Academic Literacy \\ University of Pretoria \\ PRETORIA \\ E-mail: albert.weideman@up.ac.za
}

\section{Abstract \\ The idea of lingual economy}

A number of philosophical concepts in linguistics may be conceptualised as primitives or founding concepts. Many of these are historically significant; $c f$. the concepts lingual system; lingual position and sequence, lingual constancy. Less obvious primitives are ideas of spheres of discourse, text type and acceptability. Generally, such foundational notions may be characterised either as constitutive concepts or as regulative ideas. This article will discuss one such regulative linguistic idea, viz. lingual economy, especially as this was articulated in the work of the ethnomethodologists on turn-taking. Like many other linguistic primitives, this idea constitutes a significant advance in our understanding of things lingual. The analyses referred to below give insight into the normative dimensions of our communicative ability to function as lingual subjects within the material lingual sphere of conversation. These analyses constitute an advance on earlier analyses of conversation, where the overall impression is that it is "random", forever edging towards indeterminacy and chaos. We may currently build upon the remarkable explanations, first given by ethnomethodology, for lingual distribution, equality, lingually scarce resource, and so forth. The article will argue that these relate to significant regulative ideas that disclose the structure of the lingual dimension of reality.

\section{Opsomming}

\section{Die idee van 'n linguale ekonomie}

'n Aantal filosofiese begrippe in die taalkunde kan gekonseptualiseer word as "primitiewe" of grondbegrippe. Sulke begrippe is gewoonlik histories betekenisvol: vergelyk die konsepte linguale sisteem, posisie en konstantheid, asook die 
linguale idees van diskoerstipe, tekstipe en aanvaarbaarheid. Ons kan sulke nosies as konstitutiewe begrippe of regulatiewe idees beskou. Hierdie artikel handel oor die regulatiewe idee van linguale ekonomie, en die hantering daarvan in die werk van die etnometodoloë oor beurtwisseling. Soos in die geval van ander linguistiese primitiewe, dra hierdie idee betekenisvol by tot ons begrip van die linguale. Die artikel verwys na analises wat insig gee in die normatiewe dimensies van ons kommunikatiewe vermoë om as linguale subjekte op te tree in die sfeer van gesprekvoering. Hierdie analises neem ons veel verder as vroeëre analises wat geïmpliseer het dat gesprekke deur hulle lukraak koers gekenmerk word, en altyd maar op die rand van chaos beweeg. Hulle maak dit moontlik om voort te bou op die merkwaardige verklarings van onder andere linguale distribusie, gelykheid en skaarste waarvoor die etnometodoloë ons oë oopgemaak het. Die artikel argumenteer dat hierdie regulatiewe linguistiese idees die struktuur van die linguale aspek van die werklikheid betekenisvol vir ons ontsluit.

\section{Linguistic primitives}

This article conceptualises linguistic primitives as belonging to a class of foundational theoretical concepts in linguistics. Since they are characterised as foundational concepts, this means that they are, in essence, founding concepts of the discipline, and in that sense, philosophical. Though they refer to concepts used within the discipline of linguistics, they derive at least part of their meaning from some coherent foundational or philosophical framework. This article utilises the philosophical framework developed by Dooyeweerd (1953), and especially his idea that reality has a modal horizon that allows our theoretical analysis to conceptualise a multiplicity of unique, mutually irreducible, yet interconnected aspects. By viewing these modalities as irreducible but interconnected, Dooyeweerd's approach in principle avoids the reductionist pitfalls that impede theoretical concept formation whenever one mode of reality is absolutised, and all others are subsumed under it.

In linguistics, there is a long line of investigation that, to a greater or lesser extent, has attempted to utilise this framework by showing how the lingual mode of experience, which defines the field of investigation of linguistics, coheres or analogically reflects all the other aspects of reality: the numerical, spatial, kinematic, physical, organic, sensitive, logical, formative, social, economic, aesthetic, juridical, ethical and confessional. The analogical connections of the lingual aspect with earlier (foundational or constitutive) and later (regulative) aspects yield, upon analysis, a number of linguistic pri- 
mitives. In a recent analysis done in terms of such a framework (Weideman, 2008), I have, following Hommes (1972) and others (De Jongste, 1949; 1956; Verburg, 1951; 1965; 1971; 1976; Strauss, 1967; 1970; 1971; Yallop, 1978; Weideman, 1981; Bakker, 1984) and contrary in some respects to, for example, Hoogland (2005:36) and Visagie (2006:202), presented a foundational articulation of various such linguistic primitives or elementary systematic concepts of linguistic theory.

The further starting point of this article is that such systematic concepts are closely linked with the history of the discipline. Many of these are of significant historical interest: compare, for example, the notion of lingual system (as in work from De Saussure to Chomsky); that of lingual position and sequence (as in structuralist linguistics); and the concepts of lingual constancy and movement (as in transformational grammar). Less obvious, perhaps, but equally important are notions of lingual spheres of discourse, text type and lingual acceptability that normally fall within the purview of the linguistic subdisciplines of pragmatics, discourse analysis and text linguistics. Such systematically and historically important and influential concepts are related to the coherence between the lingual dimension of reality, which delimits the field of study of the discipline of linguistics (Weideman, 1981; 2008), and other aspects of reality, such as the numerical, the spatial, the kinematic, the logical, the formative, the social, and so forth. For example, the notion of lingual system that De Saussure (1966) was so influential in identifying, articulates the coherence between the lingual and the numerical: a system of lingual norms is a unity within a multiplicity of norms. Similarly, the factual position and sequence of lingual elements, as this was explicated in the work of the structuralists, provides evidence of the connection between the lingual and the spatial dimensions of our world. The notion of lingual constancy (and also the regular positional movement of lingual elements) is an analogy that lies at the heart of transformational grammar, and relates to the link between the lingual dimension of reality and the kinematic. No doubt, similar analogical concepts may be discovered in other, more recent approaches to linguistic conceptualisation. Cognitive linguistics (Langacker, 1987; 1991; Dirven \& Verspoor, 1998), though by its own admission an approach that is not part of mainstream linguistics (Langacker, 1987:v), is one such approach that echoes many of the concerns that are articulated in the foundational framework that I have been working from. Apart from its concerns with "the conceptual clarification of fundamental issues" (Langacker, 1987:1), its attention to the notions of expressive (lingual) extension (space) 
and how we perceive and cognitively process objective lingual facts in terms of semantics and syntax is without doubt of importance to a foundational linguistic analysis. A similar case can be made for the importance of systemic functional grammar (SFG), that builds upon the work of Halliday (1985). The insights of SFG form a very important bridge across a major fault line in linguistic theory also oriented to in cognitive linguistics - that between formal linguistics and sociolinguistic analyses. As will become clear below, the focus of this article of necessity has to exclude a serious and separate treatment of such approaches if one is to do justice to them. Similarly, the minimalist turn that transformational grammar has taken (Chomsky, 1995), though ostensibly concerned with notions of economy and simplicity as conditions for universal grammar (Chomsky, 1995:168-171) may be of interest in that respect, but fall outside the scope of this article.

Generally, such foundational notions as are placed in the theoretical spotlight by the analysis of the analogical link between the lingual and other experiential aspects may be characterised either as constitutive concepts or as regulative ideas. The examples of the links or analogies between the lingual and the aspects preceding it that are given in the previous paragraph belong to the set of elementary linguistic concepts. In that sense the numerical, spatial and kinematic aspects are "earlier" aspects than the lingual, and such concepts are, by that token, constitutive. Those connections between the lingual dimension of reality and the aspects following it, on the other hand, are elementary linguistic ideas or limiting - in the sense of transcending - concepts. Since the social, economic, juridical and ethical dimensions of reality are subsequent or "later" aspects in relation to the lingual, a systematic investigation of their coherence with the lingual will only be able to grasp that linkage in terms of a set of anticipatory moments, or a set of limiting concepts or regulative ideas. If we take as a final example the analysis of the social anticipations in the structure of the lingual aspect (an analysis that yields a linguistic idea), we encounter notions of lingual spheres of discourse, each with their own normative requirements that variously determine the factual lingual text types that operate within them, and ideas of lingual acceptability within a differentiated number of spheres of discourse (cf. Weideman, 2008: Chapter 14).

A third assumption that this article makes, and will seek to illustrate in the analysis that is offered, is that constitutive elementary linguistic concepts and regulative linguistic ideas are interdependent. In the development of a systematic linguistic methodology, the in- 
vestigation of constitutive linguistic concepts must be complemented both by an enquiry into regulative linguistic ideas, and by a systematic linguistic analysis of the various complex linguistic concepts. Moreover, the conceptual understanding of one set of such linkages or analogies is not really possible without either implicit or sometimes explicit reference to other analogies.

Among the limiting concepts that should be reviewed in such an investigation are the linguistic ideas of normative and factual lingual economy (Hjelmslev [1963:94 ff.] includes in this respect the phenomena of aposiopesis, abbreviation and catalysis), factual and normative lingual harmony, lingual accountability, lingual integrity and lingual trust. These are ideas that link the lingual aspect to the economic, aesthetic, juridical, moral and confessional aspects of experience.

The analysis that I offer in Weideman (2008) illustrates, I believe, that the analogical connections between the lingual aspect of our experience and the other temporal modalities yield not a single analogy to be analysed, but normally offer a whole set of retrocipations (in the case of constitutive analogical moments) or anticipations (analogies looking forward to the relationship of the lingual modality with those aspects following it in the temporal order). As I have pointed out above, while the former are analysable in terms of theoretical concepts, the latter connections are conceptually clarified in terms of linguistic limiting concepts or ideas.

The main purpose of the current article is therefore to take an element of a linguistic limiting concept, that of lingual economy, further along the analytical track that has been indicated by the systematic framework briefly described above. As will be shown, the notion of lingual economy cannot be understood without reference to other analogical relations or sets of relations, but in fact deepens the systematic exploration of these. In a very specific sense, the idea of lingual economy that will be systematically articulated below enhances our understanding of the social disclosure of language in different material lingual spheres, which is discussed in detail in Weideman (2008: Chapters 4 and 14). The regulative idea of a lingual economy, in which the lingual aspect of experience anticipates the economic dimension, is mediated, in fact, through such social anticipations or analogies within the lingual aspect. Although the current discussion also contains new references to some of the critiques of the work on the idea of a lingual economy that will be discussed below, I shall freely use the material and analyses that 
are discussed in a broader context and detail in Weideman (2008: Chapter 15).

\section{The idea of lingual economy}

There are naturally all kinds of intuitive and practical everyday notions associated with the idea of lingual economy. One may think, for example, of judgments we make of an interlocutor's loquaciousness or taciturnity, or of the more intellectually sophisticated assessments we might make of the economy of expression that is associated with certain forms of verbal art, in particular poetry, which achieves a remarkable density through its utilisation of a number of lingual and other symbolic resources.

Then there is of course the further temptation to conceive of the analogical modal link between the lingual dimension of our experience and the economic dimension of reality in terms of the concrete phenomenon of language and its role in the sphere of economic life, in other words in the world of trade, commerce and financial transactions. These are no doubt interesting issues. The way that language acts as barrier to commerce and trade, or the way in which economic considerations influence the power that some languages gain on a global scale, while others stand to lose, are complex issues that are studied within the realm of language management or planning, as well as in language politics, and are therefore more properly treated in these subfields of applied linguistics (or in development economics, as Van Langevelde, 1997 and 1999 have done for Friesland and minority regions). I would argue that, for systematic reasons, the analysis of these phenomena be postponed until we have come to a better conceptual understanding of the elementary linguistic concepts that concern the abstract modal relationships between these two dimensions. This does not mean that they have a lower conceptual or theoretical status; quite the contrary: such concrete issues are much more complex, and the problems that they throw up need deliberate and sustained attention, and are worthy of consideration from a multiplicity of perspectives.

Instead, I propose to set out below a single illustration of how, in the theoretical approach known as ethnomethodology (cf. Sacks, et al., 1974; Goffman, 1981; Sacks, 1984; Schegloff, 1992; 2001; Heritage \& Atkinson, 1984; Schegloff \& Sacks, 1973), a breakaway school of sociology, we find a theoretically exceptional treatment of the idea of lingual economy. Their analyses enlighten us as regards the wonderfully complicated nature of lingual interaction when our theore- 
tical view ventures beyond the consideration of the expressive kernel of the lingual modality to an analysis of the structuredness of the shared expression or communication that lingual subjects attempt every day. The analysis engages here with a social analogy within the structure of the lingual aspect. If shared expression or communication provides the starting point for this analysis, it situates the lingual facts that are brought into view squarely within the social domain, or what I have been calling the social anticipations of the lingual aspect. That, in turn, immediately places spoken interaction in the theoretical spotlight. In pointing out the differences between Grice's (1975) "theory-driven" methodology and that of the "data-driven" approach of the ethnomethodologists, Svennevig (2001) is correct in observing that our

claims about spoken interaction are based on theoretical primitives (such as meaning, rationality and communication).

These primitives indeed are foundational linguistic concepts that express the connections between the lingual dimension, and, respectively, the logical aspect of experience (in the concepts of factual lingual identity, rationality or meaning) and the social (lingual expression that is shared with others to deepen into communication). However, we should also acknowledge that the ethnomethodological articulation of the idea of a lingual economy operating in spoken interaction proceeds from just such a primitive or foundational linguistic idea, in this case the anticipation by the lingual of the economic aspect of reality. In the illustration of lingual economy that will be dealt with below, lingual economy will be conceptualised as a factual scarcity of a lingual resource - a turn at talk - that is resolved, especially in one form of talk, conversation, with reference to its more or less equal distribution through the orientation that we have to a normative lingual system for sharing or distributing such a resource. In this formulation, the idea of lingual economy refers to what one reviewer has called the capitalist notion of economy (scarcity) and the socialist idea of achieving (equitable) distribution. The system of turn-taking that will be referred to below thus encapsulates both scarcity and distribution.

In the illustration that follows, I shall freely use some earlier material and analyses that I have made individually or in collaboration with others (Weideman, 1984; 1985; 1988; Weideman, et al., 1986; Weideman \& Verster, 1988). 


\section{A system for lingual sharing}

The analyses that the school of ethnomethodology made have been particularly useful for us in gaining insight into the normative dimensions of our communicative ability to function as lingual subjects within the material lingual sphere of conversation. These insights, I shall argue, have taken us much further than the initial, preliminary analyses of Crystal and Davy (1976), where the overall impression is that conversation is "random", forever edging towards indeterminacy and chaos. Most of the examples cited in this early study are of a lexical and syntactic nature; that is, they use factual lingual units at word and sentence level.

We should note, however, that once we take the study of human lingual competence and action beyond the notion of grammatical competence, other considerations emerge, and other levels of lingual object formation come into play. Thus it is with the analysis of conversation. Far from being random and indeterminate, conversation analyses have shown such talk to have a remarkably tight and economical organisation.

Central to this analysis is the idea of turn-taking in conversation. It is of course true that the lingual economy that is effected by means of turn-taking among those sharing in communicative interaction is not limited to conversation. Conversation is only one form of talk: that which is conducted among equals in an associative relationship. In most forms of talk, done within the various material lingual spheres of discourse that are referred to in Weideman (2008), some normative system of turn-taking is indeed operative. Take for example the allocation of turns at talk in a classroom, that has been investigated by Greyling (1987; cf. too Coulthard, 1985; Duff, 2002; Storch, 2004; Arthur \& Martin, 2006) and others. Such is the inequality in this form of institutional talk that in conventional classrooms the teacher normally occupies two-thirds of this scarce resource, in initiating a typical exchange by eliciting information, and ending it by giving feedback to the learner's response. Similarly, in ecclesiastical settings, which make up another institutional context, there may be predetermined and liturgically or ritually specified measures of how turns at talk are distributed. Parliamentary debates (cf. Shaw, 2000) and courtroom discourse provide further examples of institutional lingual interaction, and there have even been studies of how audience applause - a non-verbal, but certainly lingually meaningful action - in all kinds of settings is both allowed, elicited and achieved (cf. Levinson, 1983:301). 
For conversation analysts, however, the central problem was to explain how participants at talk manage in a lingual context that is associational, that is a context in which there is neither accepted authority, nor a more or less durable relationship between the members - durable referring here to the possibility of the relationship lapsing when a member (terminally) falls away, unlike in institutional relationships, that have a durability beyond the coming and going of individual members. How, in a relationship that is characterised rather by equality between participants, do they manage a lingually economical, and to bring in a juridical analogy as well, fair way of distributing access to a scarce lingual resource: a turn at talk? What lingual subjects in the communicative event that we call conversation need, is, as Levinson (1983:297) puts it:

... a sharing device, an 'economy' operating over a scarce resource, namely control of the 'floor'. Such an allocational system will require minimal units (or 'shares') over which it will operate, such units being the units from which turns are constructed.

The idea of turn-taking as a set of norms or a system of lingual economy is so deceptively obvious that, before the advent of ethnomethodological analyses, very little attention had been paid to it. Of course, like many other theoretical ideas, the idea of a turntaking system that is operative in conversation has been strongly contested (for example by O'Connell et al., 1990; Cowley, 1998), but these either proceed from a misunderstanding of the methodological and procedural starting points of conversation analysis (cf. for example Sacks, 1984; Schegloff, 1992; 2001) or misrepresent both the positions and the claims made by ethnomethodologists. What is important, however, is neither their contestation nor the theoretical endurance of these ideas in spite of their being challenged, but the historical significance of the insight, that opened up a dimension of linguistic conceptualisation that we did not have before. The earlier analyses of conversation referred to above failed to recognise the potential significance of discovering an organisational structure in conversation, and also the host of explanatory problems that it evokes.

\section{Turn-taking and conversation}

One of the hardest questions to answer, if one agrees with the ethnomethodologists, is why it is so that turn-taking is central to conversation. When we look at an actual instance of conversation, it is not difficult to observe that one participant talks, stops, that at that 
point another starts, talks, stops, at which point the turn at talk is transferred to the first speaker, and so on.

One possible explanation for this is that in the roughly equal (in the sense of recurrent) distribution of talk across the turns of different speakers there is evidence of the (social) equality of the speakers. Note that, while the notion of lingual distribution is certainly an articulation of an echo of the economic modality (which is originally concerned with the allocation of scarce resources) within the lingual sphere, and the idea of equality concerns the social specifications of the role of lingual subjects, the concept of lingual recurrence most probably echoes and conceptually broadens the constitutive relation between the lingual aspect and the kinematic. When the opportunity for talk is as evenly and recurrently distributed as in conversation, it is a way of securing, a ratification, of the equality of participants. I return below to the articulation of the idea of ratification or lingual confirmation which, in its turn, is a juridical analogy within the structure of the lingual aspect.

To see why this explanation is plausible, we need to compare the relatively equal distribution of turns at talk in conversation with other forms of talk that were referred to above. In non-associational, institutional settings for example, there is often a marked and widespread lack of an equal distribution of turns (Greyling, 1987; Coulthard, 1985; Arthur \& Martin, 2006). The lecture is a case in point, for here one of the participants holds forth for almost any length of time, and moreover, has the ability to withhold from other participants any opportunity of talking, by employing a number of devices: "Let me just finish this point ..." is a technique often used to counter an interruption signal from one of the other participants, be it in the form of a cough, a raising of the hand, the clearing of a throat or any combination of these. Actually, then, it is not so much the size of the turn that suspends the equality of the participants, it is more likely the presence of an authority to allocate (or withhold allocation of) turns. This is probably the case in all institutional settings, even those where one would expect the power gradient between the person who has the authority to influence the allocation of turns and the co-participant at talk to be less steep, as in receptionist-patient exchanges (cf. Hewitt, 2006:142; also 34).

The same inequality seems to reign in law courts, religious services and meetings, where there are either ritualised ways of allocating turns, or where one participant has the acknowledged right to allocate turns (be such a person presiding officer of the court, chair- 
person, or whatever). There are in these types of discourse signs of the authority relationship that ordinary conversation lacks.

One of the most interesting observations that follows from turntaking or speaker change in conversation is the remarkable lack of overlap between speakers. It has been calculated that less than 5\% - a minimal amount by any standard - of talk overlaps between the turns of ratified speakers (Levinson, 1983:296). In the moment of speaker ratification, we find an echo of a juridical analogy in the lingual aspect: once rightfully confirmed as speaker, and acknowledged as such by co-participants at talk, a speaker has a defensible, allocated space in which to speak. What is even more remarkable about the lack of overlap between speakers is that at the same time gaps between speakers' turns are almost immeasurably small only a few tenths of a second, and sometimes considerably shorter. In spite of speaker change, talk is therefore continuous, always in progress. This is a significant enhancement of our understanding of the concept of lingual continuity, which is another linguistic primitive, related to the analogical link between the lingual and the spatial dimensions (for a more detailed discussion, cf. Weideman, 2008: Chapter 7). It is an illustration, once again, that the constitutive linguistic concept of continuity is enlivened and developed further by the regulative linguistic ideas that flow from the modal interconnections between the lingual and the social, economic and juridical analogies, since the idea of lingual continuity is now conceived of as a communicative space (the turn) in which lingual subjects share expression or meaning in an economically moderated way that not only allows for the sharing of such lingual space, but rightfully distributes and allocates it.

\section{An orientation to norms for conversation}

How can one explain this? Conversation analysts suggest a rule to which speakers are subject that explains both the absence of gaps between turns and the simultaneous lack of overlap, i.e. the continuity of talk in conversation:

Rule: At least and not more than one party talks at a time

This rule has a normative character, and does not function as a natural law which is inviolable. Indeed, speakers do in fact overlap (marked //) as in the following example from Sacks et al. (1974:702): 
[1] Desk: What is your last name // Lorraine?

Caller:

Desk: What?

Caller: Dinnis

(Sacks et al., 1974:702.)

The amount of overlap, however, either remains negligible, or can at least be remedied, as in the above, since both speakers know that a fundamental rule has been violated, and collaboratively set out to rectify such deviation in their first subsequent round of turns. In this lingual collaboration, we see another dimension of the social analogies within the lingual modality. Furthermore, in the normative lingual orientation that co-participants in conversation have towards such violations, we find an illustration of the idea of lingual accountability - speakers set out to rectify and repair the continuity that is to be jointly and collaboratively achieved - which expresses in yet another way the anticipations within the lingual aspect of our experience of the juridical and social.

That knowledge of the rule above is part of our subjective communicative ability or competence is also evident, firstly, in the fact that we know, within milliseconds apparently, that in the case of speakers competing for a turn one has started first. This will probably be the one who will continue while the other drops out, as in the example from Svartvik and Quirk (1980:47; adapted from p. 786$797 ;+$ marks the end of overlap):

[2] A: ... I thought he was going to talk us into having to do another complete set of ... set books for that bloody philology // paper

*B: $\quad$ Erm +

${ }^{*} \mathrm{~A}$ : If he had l'd // have said ...

${ }^{*} \mathrm{~B}$ : the ... the other the other the other + the other man ehm who ... I thought was going to get you wild was Potter.

*A: (swears) l'll crown that bastard before I'm finished with him.

(Svartvik \& Quirk, 1980:47, adapted from 786797; + marks the end of overlap.)

Secondly, if there is almost exactly simultaneous talk, we have techniques to snatch a turn or to let it go by either upgrading our tone and pitch, or by fading, as in

[3] J: But this // person that DID IT + IS GOT TO BE

*V: $\quad$ If I see the person

* J: ... taken care of

(Levinson, 1993:301.) 
and

[4] A: ... It is sui generis ..., you see

B: Yes.

A: $\quad$ Ehm ...

B: $\quad / /$ But I I+

A: THIS IS + this is one of the things that eh one of the many things eh in English structure which is ehm an item in a close system.

(Svartvik \& Quirk, 1980:46 f.; adapted from p. 738-750.)

However interesting these observations may be, ethnomethodology requires that we offer a local explanation for them. If we indeed, as part of our communicative competence, possess the general ability to recognise and act upon overlap, while striving to maintain and uphold the fundamental rule of talk, that at least but not more than one party talks at a time, then it should be obvious that we have some kind of system for achieving this. For if talk must normatively be continuous, then, given the fact of turn-taking or recurrent change of speaker, we must have some means of achieving such change.

How, in other words, do we hand over turns to another in speaking? One obvious way of transferring a turn at talk to another lingual subject is by nominating the next speaker. In other kinds of talk this occurs frequently, cf. parliamentary debates

[5] I now call upon the honourable member for Upington ... or press conferences

[6] Mr. Jackson, from the Daily Star?

It is, however, clear that speaker nomination has to be done much more delicately and subtly in conversation. It would be ludicrous if in conversation we are forever being formally and explicitly called upon to speak. And yet we are called upon to speak, and if we reflect upon it, are often selected as next speakers in continuing conversation, by means of address terms tagged to questions or statements, checks, and so on:

[7] Are you coming, David?

[8] You've been here before, right?

[9] Beg your pardon?

By looking closely at the data, conversation analysts have, however, come up with a whole system of rules to effect speaker change. They have found that turns form units, the ends of which may act as places for transition. These possible completion points are called transition relevance places or TRPs. With this in mind, one may then 
formulate the rules for speaker change in ongoing conversation by ratified speakers. They are $(C=$ current speaker; $N=$ next speaker):

Rule 1 (applying at the initial TRP of any turn):

(a) If $C$ selects $N$ in his current turn, then $N$ and no other must speak.

(b) If $C$ does not select $N$, then any party may elect to speak, and the first party to do so has rights to the next turn.

(a) If $C$ has not selected $N$, and no other party self-selects under rule $1(b)$, then $C$ may, but need not, continue.

Rule 2 (applying at all subsequent TRPs):

When by rule 1 (c) $C$ has assumed the right to take another turn at speaking, then at the next TRP rules 1(a)-1(c) re-apply, and so on recursively until speaker change is effected.

(Adapted from Levinson, 1983:298; cf. too Sacks et al., 1974:704.)

These "rules" are again normative, that is, orientation points or starting places for the collaborative lingual effort we call conversation. It is clear that the rules must be attended to by both $S$ (speaker) and $H$ (hearer) if they are co-operatively to accomplish a conversational exchange, i.e. transform an $S: H$ relationship into a C:N one.

Instances of rule 1(a) applying at the first possible completion point for a turn are straightforward enough. Of course, [7]-[9] above will be units at the end of which one may normally expect transition to $N$.

But what about the operation of the other rules? We have, in other contexts already looked at examples of this, but another clear example of where self-selection occurs is marked * in the following exchanges (the phenomenon marked ${ }^{* *}$ will be discussed below):

[10] A: Ih ... is ... is it this year that eh Nightingale goes?

B: Eh no, next year.

${ }^{*}$ A: $\quad$ Ehm sixty / f ...

B: $\quad$ Sixty five $+\ldots$

${ }^{* *} \mathrm{~A}: \quad$ Four, sixty five

B: Yeah.

*A I thought it was before sixty-five. || So it's not until next year that // the job will be advertised

${ }^{*} \mathrm{~B}$ January I suppose there + may be an interview round about January.

A Yeah.

(Svartvik \& Quirk, 1980:38; adapted from p. 238-247.) 
In all the turns marked * in the above, self-selection (as opposed to other, or $C$-selection) has occurred because there are no $\mathrm{N}$ selection devices present in the preceding turn, and transition takes place at the end (TRP) of this turn. The operation of rule 1(c) is also evident in A's fourth turn (marked II).

The normative character of rules 1 and 2 also provides, of course, for their violation, as in the intentional interruption

[11] C: Well, I wrote what I thought was a a ... a reason//able explanation

F: $\quad$ I think it was a very rude letter (Levinson, 1983:299.)

which violates the provision for taking up a turn at a TRP.

Moreover, we have, by virtue of the normative character of these rules, an explanation for significant silences. In [12], A's utterances select $B$ as $N$, but $B$, in initially refusing to heed rule 1 (a) finally yields to the normative force of the rule, which is dependent on the connection between the lingual dimension of experience and the physical aspect of energy-effect, only on his last turn:

[12] $A$ : Is there something bothering you or not?

A: Yes or no?

(1,0 second gap)

A: Eh?

(1,5 second gap)

B: No.

(Levinson, 1983:300.)

Apart from explaining why B's "No" probably means "Yes", the rules for achieving speaker change also clarify the sense that lingual subjects, as speakers, have of significant silences. Yet it is astonishing to see how quickly, under normative pressures for conversational continuity, they become so. Silences between turns are not tolerated in this kind of talk, and call up complaints of the kind

[13] You're not listening to me!

[14] C: Mac

$\mathrm{J}$ : Yes

C: $\varnothing$

(2 seconds)

$\mathrm{J}$ : Hey, trying to waste my time or something?

(Weideman et al., 1986:97.)

Since both the fundamental rule for conversation and the rules for achieving change of speaker are normative, they do, as we have 
seen, allow not only silence(s), but also overlap. The collaborative nature of conversation, however, provides for specific ways of extricating oneself from the chaos that would result if violations were allowed to stand without remedy. One such remedy, where overlap occurs, is the recycling of the part obscured by overlap, as in [2], [4] and [10] above (marked ** in the latter case), whereby repair is effected.

Repair can also, in the case of inadvertent overlap, be called for in the form of a check, as in Desk's second turn in [1], and effected by the subsequent turn of $N$.

The existence of possible completion points for turns presents yet another problem not only for Ns, who have to attend to TRPs to avoid complaints in the form of [13], but also for Cs who for some reason wish to hold the floor, i.e. in formal terms, strive to avoid the application of rule 1 (b) and to continue talking past possible completion points (TRPs) by rule 1 (c). Thus $C$ may employ what are known as incompletion markers by conversation analysts: but, and, however constitute devices for temporarily suspending the normative precedence of rule 1(b) over 1(c). Such markers, however, are only successful in avoiding application of rule 1(b) in some instances, as

[15] B: Joe has goh ... got it of course // and

A: $\quad$ Has he +

${ }^{*} \mathrm{~B}$ and presumably those are the two people who do it.

(Svartvik \& Quirk, 1980:39; adapted from p. 324-327.)

but not in others:

[16] B: That's what it would amount to, isn't it, but l'd plan to get // somebody ...

A: Well he wouldn't have to hire + somebody you see, he'd have you built in.

(Svartvik \& Quirk, 1980:39; adapted from p. 299-302.)

In fact, more than a quarter of all interruptions occur after conjunctions (Coulthard, 1985:64).

Yet other incompletion markers are openings with since, if, or, more elaborately,

[17] l'd like to make two comments on that. First ... Second ...

Of course, no "incompletion marker" can guarantee that $C$ keeps the turn, but they do show up $N$ as violating the norm by interrupting, which may be decidedly anti-normative behaviour (see [11] above). 
The most sophisticated solutions to the problem of $C$ wishing to hold the floor occur before storytelling or jokes. These special incompletion markers are called story-prefaces. Stories and jokes are often begun with

[18] Have you heard the one about ...

[19] There were these three girls ...

The suspension of the rules for turn-taking by story-prefaces calls forth another problem for Ns, of course: how do they know that the floor is again open, and that the rules are in operation again?

In the case of jokes the solution is easy, for they have recognisable endings, or punchlines. The laughter that is normative after the punchline paves the way for a resumption of rule-application. But in the case of stories it is of course less easy to perceive endings (which in their turn call for nods, comments, or both) and resumption of talk by rule 2 .

Thus, in probing the idea of turn-taking, ethnomethodological analysis has given us an insight into the remarkable normative system that helps us to distribute a factually scarce lingual resource, and one that is "valued" by lingual subjects - a turn at talk.

\section{A broadening of the concept of objective factual lingual unit}

Some of the phenomena of conversation that have been considered in the previous section also concern its lingual wholeness and continuity - specifically the continuous, sequential nature of talk that disallows both gaps and overlap, as well as the beginnings and endings of shorter and longer turns. These two concepts are related, respectively, to the analogies of the numerical and spatial dimensions of experience within the structure of the lingual aspect. It should be obvious that the current discussion significantly broadens and opens up the constitutive notions of lingual objects, restricted as these are to factual units such as morphemes, words and sentences in "formal" linguistics, that is, in that part of linguistics that attempts to focus and deal exclusively with constitutive linguistic concepts, as these have been defined within the framework employed here.

The conversational phenomena that were considered above were discussed within the context of an analysis that focused on the norm-side of the lingual aspect, specifically on the normative analogies that link the lingual aspect of our experience with the economic. This analysis has allowed us to conceptualise the turn- 
taking system discovered by conversation analysts in talk among equals as a device or norm for a shared economy of a scarce lingual resource. The analysis also shows that lingual subjects have an orientation towards mutuality in talk, and towards responding in their formation of lingual objects to a system of norms that allows each enough talking space, and the opportunity to share their expression - often called the "co-construction of meaning" - with selected and ratified others.

\section{List of references}

ARTHUR, J. \& MARTIN, P. 2006. Accomplishing lessons in postcolonial classrooms: comparative perspectives from Botswana and Brunei Darussalam. Comparative education, 42(2):177-202.

BAKKER, D.M. 1984. Kritische notities bij Ferdinand de Saussure's cours. Philosophia reformata, 49(1):1-34.

CHOMSKY, N. 1995. The minimalist program. Cambridge: MIT.

COULTHARD, M. 1985. An introduction to discourse analysis. Harlow: Longman.

COWLEY, S. 1998. Of timing, turn-taking, and conversations. Journal of psycholinguistic research, 27(5):541-571.

CRYSTAL, D. \& DAVY, D. 1976. Investigating English style. London: Longman.

DE JONGSTE, H. 1949. Taalkunde en taalbeschouwing. Philosophia reformata, 14(1):3-42; (2):49-57.

DE JONGSTE, H. 1956. On symbols. Philosophia reformata, 21(4):162-174.

DE SAUSSURE, F. 1966. Course in general linguistics. New York: McGraw-Hill.

DIRVEN, R. \& VERSPOOR, M. 1998. Cognitive exploration of language and linguistics. Amsterdam: Benjamins.

DOOYEWEERD, H. 1953. A new critique of theoretical thought. 4 volumes. Amsterdam: Paris.

DUFF, P.A. 2002. The discursive co-construction of knowledge, identity and difference: an ethnography of communication in the high school mainstream. Applied linguistics, 23(3):289-322.

GOFFMAN, E. 1981. Forms of talk. Oxford: Blackwell.

GREYLING, W.J. 1987. The typicality of classroom talk and its relevance for the training of teachers. Bloemfontein: University of the Free State. (Unpublished M.A. dissertation.)

GRICE, H.P. 1975. Logic and conversation. (In Cole, P. \& Morgan, J.L., eds. Syntax and semantics. Vol. 3: Speech acts. New York: Academic Press. p. 41-58.)

HALLIDAY, M.A.K. 1985. An introduction to functional grammar. London: Arnold.

HERITAGE, J. \& ATKINSON, J.M. 1984. Introduction. (In Atkinson, J.M. \& Heritage, J., eds. Structures of social action: studies in conversation analysis. Cambridge: Cambridge University Press. p. 1-15.)

HEWITT, H. 2006. Front desk talk: a study of the interaction between receptionists and patients in general practice surgeries. Edinburgh: The University of Edinburgh. (D.Phil thesis.) http://www.era.lib.ed.ac.uk/handle/ 1842/1482 Date of access: 22 Sept. 2007. 
HJELMSLEV, L. 1963. Prolegomena to a theory of language. Tr. by F.J. Whitfield. Madison: University of Wisconsin Press.

HOMMES, H.J. VAN EIKEMA. 1972. De elementaire grondbegrippen der rechtswetenschap: een juridische methodologie. Deventer: Kluwer.

HOOGLAND, J. 2005. De reformatorische wijsbegeerte in het gedrang. Beweging, 69(4):33-42.

LANGACKER, R.W. 1987. Foundations of cognitive grammar. Vol. 1: Theoretical prerequisites. Stanford: Stanford University Press.

LANGACKER, R.W. 1991. Concept, image and symbol: the cognitive basis of grammar. Berlin: De Gruyter.

LEVINSON, S.C. 1983. Pragmatics. Cambridge: Cambridge University Press.

O'CONNELL, D.C., KOWAL, S. \& KALTENBACHER, E. 1990. Turn-taking: a critical analysis of the research tradition. Journal of psycholinguistic research, 19(6):345-373.

SACKS, H. 1984. Notes on methodology. (In Atkinson, J.M. \& Heritage, J., eds. Structures of social action: studies in conversation analysis. Cambridge: Cambridge University Press. p. 21-27.)

SACKS, H., SCHEGLOFF, E.A. \& JEFFERSON, G. 1974. A simplest systematics for the organization of turn-taking for conversation. Language, 50(4):696-735.

SCHEGLOFF, E.A. 1992. On talk and its institutional occasions. (In Drew, P. \& Heritage, J., eds. Talk at work: interaction in institutional settings. Cambridge: Cambridge University Press. p. 101-134.)

SCHEGLOFF, E.A. 2001. Discourse as interactional achievement. Vol. 3: The omnirelevance of action. (In Schifrin, D., Tannen, D. \& Hamilton, H.E., eds. The handbook of discourse analysis. Oxford: Oxford University Press. p. 229-249.)

SCHEGLOFF, E.A. \& SACKS, H. 1973. Opening up closings. Semiotica, 8:289327.

SHAW, S. 2000. Language, gender and floor apportionment in political debates. Discourse \& society, 11(3):401-418.

STORCH, N. 2004. Using activity theory to explain differences in patterns of dyadic interactions in an ESL class. Canadian modern language review, 60(4):457-480).

STRAUSS, D.F.M. 1967. Wysgerige grondprobleme in die taalwetenskap. Bloemfontein: Sacum.

STRAUSS, D.F.M. 1970. Wysbegeerte en vakwetenskap. Bloemfontein: Sacum.

STRAUSS, D.F.M. 1971. Wetenskap en werklikheid: oriëntering in die algemene wetenskapsleer. Bloemfontein: Sacum.

SVARTVIK, J. \& QUIRK, R., eds. 1980. A corpus of English conversation. Lund: CWK Gleerup.

SVENNEVIG, J. 2001. Abduction as a methodological approach to the study of spoken interaction. http://home.bi.no/a0210593/Abduction\%20as\%20a\% 20methodological\%20.pdf Date of access: 2 Oct. 2007.

VAN LANGEVELDE, A.P. 1997. Bilingualism and economic development in west European minority language regions: a Dooyeweerdian approach. http://som.eldoc.ub.rug.nl/FILES/reports/1995-1999/themeC/1997/97C39/ 97c39.pdf Date of access: 22 Oct. 2007. 
VAN LANGEVELDE, A.P. 1999. Bilingualism and regional economic development: a Dooyeweerdian case study of Fryslân. Groningen: Utrecht. (Netherlands Geographical Studies, 255.)

VERBURG, P.A. 1951. Enkele lijnen en feiten in de ontwikkeling der taaltheorie. (In Zuidema, S.U., red. Wetenschappelijke bijdragen door leerlingen van Dr. D.H. Th. Vollenhoven. Franeker: Wever. p. 13-22.)

VERBURG, P.A. 1965. Delosis and clarity. (In Fortman, W.F. de Gaay, Hammes, H.J., Dengerink, J.D., Langemeijer, G.E., Mekkes, J.P.A., Van Peursen, C.A. \& Stellingwerff, J., eds. Philosophy and Christianity: philosophical essays dedicated to Prof. Dr. H. Dooyeweerd. Kampen: Kok. p. 78-99.)

VERBURG, P.A. 1971. De mens in de taalkunde. (In Truth and reality: philosophical perspectives on reality dedicated to Prof. H.G. Stoker. Braamfontein: De Jong. p. 262-282.)

VERBURG, P.A. 1976. The idea of linguistic system in Leibniz. (Offprint from Parret, H., ed. History of linguistic thought and contemporary linguistics. Berlin: De Gruyter. p. 593-615.)

VISAGIE, J. 2006. Key theory and philosophy of mind. (In Lategan, L.O.K. \& Smit, J.H., eds. Time and context relevant philosophy. Journal of Christian scholarship, 42(1):202-218 - special edition.)

WEIDEMAN, A.J. 1981. Systematic concepts in linguistics. Bloemfontein: University of the Free State. (Unpublished M.A. dissertation.)

WEIDEMAN, A.J. 1984. General and typical concepts of textual continuity. SA journal of linguistics, 2(1):69-84.

WEIDEMAN, A.J. 1985. Discovering conversational units. Acta academica, Series B/2: Fokus op die taalkunde:195-207.

WEIDEMAN, A.J. 1988. Linguistics: a crash course for students. Revised ed. Bloemfontein: Patmos.

WEIDEMAN, A.J. 2008. Beyond expression: a systematic study of the foundations of linguistics. Grand Rapids: Paidea. (The Reformational Publishing Project.)

WEIDEMAN, A.J., RAATH, J. \& VAN DER WALT, P.J. 1986. Continuity and discontinuity in talk: some brief notes on summonses. SA journal of linguistics, 4(4):90-100.

WEIDEMAN, A.J. \& VERSTER, L. 1988. "Two roads diverged ...": an analysis of the achievement of partings. SA journal of linguistics, 6(4):55-68.

YALLOP, C.L. 1978. The problem of linguistic universals. Philosophia reformata, 43(1 \& 2):61-72. 


\section{Key concepts:}

lingual economy

linguistic primitives

linguistics: foundations of

turn-taking

Kernbegrippe:

beurtwisseling

linguale ekonomie linguistiese grondbegrippe taalkunde: grondslae van 
